Law \& Economics Working Papers

Law \& Economics Working Papers Archive:

2003-2009

University of Michigan Law School

Year 2003

\title{
What Counts as Fraud? An Empirical Study of Motions To Dismiss Under the Private Securities Litigation Reform Act
}

\author{
Adam C. Pritchard* Hillary Sale ${ }^{\dagger}$
}




\title{
UNIVERSITY OF MICHIGAN
}

JOHN M. OLin CENTER FOR LAW \& ECONOMICS

\author{
What COUNTS AS F RAUd? \\ AN EMPIRICAL STUdY OF Motions To DisMiss \\ Under the Private Securities Litigation ReForm ACT
}

A.C. Pritchard \& Hillary A. Sale

PAPER \#03-011

FORTHCOMING EMPIRICAL LEGAL STUDIES

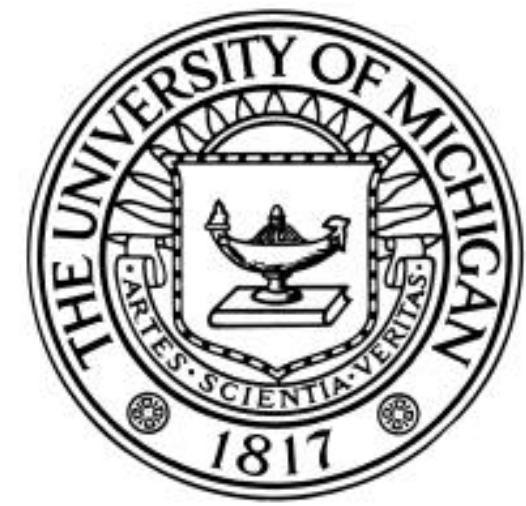

THIS PAPER CAN BE DOWNLOADED WITHOUT CHARGE AT:

Michigan John M. Olin Website

HTTP://WWW.LAW.UMICH.EDU/CENTERSANDPROGRAMS/OLIN/PAPERS.HTM 


\title{
What Counts as Fraud? An Empirical Study of Motions To Dismiss Under the Private Securities Litigation Reform Act
}

\author{
A.C. Pritchard \& Hillary A. Sale* \\ June 2004; MTDArticle19.doc
}

\begin{abstract}
This article presents the findings of a study of the resolution of motions to dismiss securities fraud lawsuits since the passage of the Private Securities Litigation Reform Act in 1995. Our sample consists of decisions on motions to dismiss in securities class actions by district and appellate courts in the Second and Ninth Circuits for cases filed after the passage of the Reform Act to the end of 2002. These circuits are the leading circuits for the filing of securities class actions and are generally recognized as representing two ends of the securities class action spectrum. Post-PSLRA, the Second Circuit applies the least restrictive pleading standard to securities claims and the Ninth Circuit applies the most restrictive.

The Ninth Circuit's post-PSLRA reputation as being a tougher venue in which to win securities fraud class actions is born out by a significantly higher dismissal rate. The differences between the two circuits are also reflected in factors that correlate with dismissal. For example, allegations of violations of accounting principles other than revenue recognition correlate negatively with dismissal in the Second Circuit. This coefficient, however, is insignificant in our regressions for the Ninth Circuit. Allegations of revenue recognition violations are insignificant in both circuits, whether or not the issuer has been forced to restate those revenues. The circuits part ways on other factors as well: the Second Circuit is significantly less likely to dismiss cases with allegations of false forward-looking statements, a surprising result given the stringent standards for such statements imposed by the PSLRA. The Ninth Circuit is significantly less likely to dismiss complaints with allegations of ' 33 Act violations and the Second Circuit is more likely to dismiss cases brought by the Milberg Weiss firm. When it comes to insider trading, however, the two circuits are both skeptical and the allegations correlate with dismissal in both circuits.
\end{abstract}

Keywords : Securities litigation, accounting fraud, insider trading.

\footnotetext{
* Professor of Law, University of Michigan, and F. Arnold Daum Corporate Law Scholar and Professor of Law, University of Iowa, respectively. This paper was prepared for the Third Annual Joe B. Davis Law and Business Program Conference at the Vanderbilt University School of Law. We are grateful to participants at that conference, as well as Michael Bongiorno, Steve Choi, Jill Fisch, Marilyn Johnson, Don Langevoort, Karen Nelson, Randall Thomas, Bob Thompson and two anonymous referees for comments on earlier drafts of this article. Melissa Williams provided invaluable assistance with the statistical analysis. Jenness Parker, Matthew Rice, and Michael Russell assisted with data collection.
} 


\section{INTRODUCTION}

What counts as fraud in securities class actions? Who wins and who loses? These questions are obviously important to the lawyers who specialize in this area, as well as the corporate officers and directors whose firms are targeted by these suits. But the questions ae also important to Congress, the SEC, and other policymakers and academics considering the deterrence and governance roles played by securities fraud class actions.

To date, little rigorous empirical investigation has been brought to bear on these questions. Most of the efforts to answer these questions analyze appellate court cases or tally up numbers of lawsuits or settlement values. Extrapolating from cases is the traditional mode of legal scholarship and it can shed insights on many issues. Our study adds to those works by utilizing regression analysis to provide a more complete picture of how this litigation works on the ground.

The dearth of solid empirical work on securities fraud class actions did not chill legislative initiatives in this area in the 1990's. Despite the lack of solid data on securities fraud class actions, Congress decided that the field was ripe for reform. The initial lobbying force behind the PSLRA was the accounting industry. Over time, hightech industry leaders, lawyers, and other frequent defendants of such class actions joined forces with the accountants. ${ }^{1}$ The concern voiced most frequently by these interest groups was that frivolous class action complaints were being filed largely for settlement value. ${ }^{2}$ Reform proponents claimed that a simple drop in a company's stock price would

\footnotetext{
${ }^{1}$ See Hillary A. Sale, Heightened Pleading and Discovery Stays: An Analysis of the Effect of the PSLRA's Internal-Information Standard on '33 and '34 Act Claims, 76 Wash. U. L. Q. 537, 555 (1998) (discussing reform movement and participants).

${ }^{2}$ See id. at 552-53.
} 
result in the filing of a complaint that, in turn, would provide leverage for settlement given the time and risk entailed in contesting such claims. ${ }^{3}$ Settlement pressure also resulted from expensive discovery demands, and reform proponents argued that nonmeritorious cases were settled simply to avoid the costs of litigation. ${ }^{4}$

Although the evidence on these claims was decidedly mixed, ${ }^{5}$ Congress generally accepted the arguments in adopting the Private Securities Litigation Reform Act of 1995 ("PSLRA"). ${ }^{6}$ The PSLRA erects a series of procedural barriers to securities fraud cases intended to discourage meritless suits and reduce the cost of defending class actions. President Clinton vetoed the legislation, expressing the view that it would deter meritorious cases of fraud, but Congress overrode his veto. ${ }^{7}$

Congress's enactment of the PSLRA is simply the first step in the effort to crack down on securities fraud class actions. Judicial interpretation and application of the PSLRA's provisions will have much to do with how the law affects issuers and investors. The process of interpretation is particularly important for the PSLRA because Congress left its cornerstone provision purposefully vague, because it could not reach agreement on a more determinate formulation. ${ }^{8}$ Not surprisingly, that vagueness has led to divergent interpretations of the PSLRA in the courts. ${ }^{9}$ Do those divergent interpretations lead to different outcomes?

\footnotetext{
${ }^{3}$ See id. at $553-54$.

${ }^{4}$ See id. at 553-54.

${ }^{5}$ See Hillary A. Sale, Judging Heuristics, 35 U.C. Dav. L.Rev. 903, n. 57 (2000) (discussing and citing articles debating arguments underlying the PSLRA).

6 Pub. L. No. 104-67, 109 Stat. 737 (1995) (codified as amended in scattered section of 15 U.S.C.).

${ }^{7}$ See 141 Cong. Rec. H15,214 (daily ed. Dec. 20, 1995).

${ }^{8}$ See Joseph A. Grundfest and A.C. Pritchard, Statutes with Multiple Personality Disorders: The Value of Ambiguity in Statutory Design and Interpretation, 54 Stan. L. Rev. 627, 652-660 (2002) (describing tacit "agreement to disagree" over the PSLRA's pleading standard).

${ }^{9}$ See id. at 667-675 (collecting cases).
} 
To answer that question, this paper examines how judges are implementing the PSLRA's barriers to suit. Specifically, we study the resolution of motions to dismiss under the PSLRA. The PSLRA makes the motion to dismiss the main event for corporate issuers. Until the motion to dismiss is resolved, the PSLRA's discovery stay prevents the plaintiffs from obtaining discovery to flesh out the allegations of their complaint. ${ }^{10}$ Thus, plaintiffs' lawyers must construct their claims of fraud out of the issuer's past filings with the SEC and press releases. Moreover, the absence of discovery means that the expense of litigation will be manageable for the issuer. If the corporation fails to get the case dismissed, however, it must suffer through an expensive and time-consuming airing of its potentially dirty laundry through the discovery process. Worse yet, the corporation faces the specter of potentially ruinous damages if the case goes to trial (particularly for those cases that are strongest on the merits). Both risk ave rsion, and, of course, the possibility that fraud actually occurred, ensure that securities fraud class actions rarely go to a jury. ${ }^{11}$ Cases that are not dismissed on a motion to dismiss or at summary judgment, and that survive class certification, invariably settle. Understanding the determinants of motions to dismiss, therefore, is a crucial piece in understanding how securities fraud class actions operate in the real world.

We proceed as follows. Part 2 provides background on securities fraud class actions and the objectives of the PSLRA. Part 3 develops a series of hypotheses regarding the determinants of outcomes of motions to dismiss in securities fraud class

\footnotetext{
${ }^{10}$ Exchange Act $\$ 21 \mathrm{D}(\mathrm{b})(3)(\mathrm{B}), 15$ U.S.C. $\$ 78 \mathrm{u}-4(\mathrm{~b})(3)$.

${ }^{11}$ Black et al. were able to find one securities case that went to trial in the last ten years. Bernard Black et al., Outside Director Liability, Working Paper No. 250, John M. Olin Program in Law and Economics, at 33 (2003).
} 
actions. Part 4 presents the results of our empirical tests of those hypotheses. Part 5 concludes.

Our findings reveal some similarities and some differences between the two circuits. We find that the law matters - the Ninth Circuit's post-PSLRA reputation as a tougher venue in which to win securities fraud class actions is born out by the data, which shows a significantly higher dismissal rate in that circuit. Somewhat surprisingly, allegations of revenue recognition violations are insignificant in both circuits, whether or not the issuer has been forced to restate those revenues. The two circuits take a similar approach to insider trading, which correlates with dismissal in both circuits.

The two circuits part ways, however, in their approach to other allegations commonly found in securities fraud complaints. For example, allegations of violations of accounting principles other than revenue recognition correlate negatively with dismissal in the Second Circuit, but this coefficient is insignificant in our regressions for the Ninth Circuit. The Second Circuit is significantly less likely than the Ninth to dismiss cases with allegations of false forward-looking statements, a surprising result given the stringent standards for such statements imposed by the PSLRA. We conclude that plaintiffs' lawyers are being more selective in making such allegations, in contrast to less precisely targeted allegations tied to insider trading. In addition, we find that the Ninth Circuit is significantly less likely to dismiss complaints with allegations of '33 Act violations than the Second Circuit is. But, the Second Circuit is more likely than the Ninth Circuit to dismiss cases brought by the Milberg Weiss firm.

\section{BACKGROUND TO THE PRIVATE SECURITIES LITIGATION REFORM ACT}


The plaintiffs' and defense bar (along with outside observers) agree that the PSLRA makes it more difficult to plead a securities fraud complaint that can survive a motion to dismiss. ${ }^{12}$ The PSLRA addressed these cases in various ways, including two that we focus on here: heightened pleading standards for securities fraud complaints and actual-knowledge standards for forward-looking statements.

\section{A. $\quad$ The Pleading Standard}

The main focus of our study is the effect of the heightened pleading standard. Most securities fraud class actions allege that the defendants violated section $10(\mathrm{~b})^{13}$ and Rule $10 \mathrm{~b}-5^{14}$ of the Securities Exchange Act ("10b-5 claims"). In Ernst \& Ernst v. Hochfelder, the Supreme Court rejected a negligence standard for 10b-5 claims, instead holding that plaintiffs alleging such claims must prove that the defendants acted with scienter. ${ }^{15}$ Scienter requires that the defendant have acted at least recklessly in making the misstatement. Thus, to state such a claim, the plaintiff must plead that the defendant made a material misstatement or omission, with scienter, and that she was injured by her reliance on that misstatement or omission. ${ }^{16}$

In their attempts to apply the scienter standard to complaints alleging 10b-5 claims, the circuits developed diverse pleading standards based on Rule 9(b) of the Federal Rules of Civil Procedure. Rule 9(b) departs from the general rule of notice pleading ${ }^{17}$ by requiring that allegations of fraud be made "with particularity," but

\footnotetext{
12 Richard H. Walker, David M. Levine \& Adam C. Pritchard, The New Securities Class Action: Federal Obstacles, State Detours, 39 ARIZ. L. REV. 641 (1997).

1315 U.S.C. $\$ 78$ j.

1417 C.F.R. $\$ 240.10 b-5$ (1992).

15425 U.S. 185 (1976).

${ }^{16}$ Id. at 197.

${ }^{17}$ See Fed. R. Civ. P. 8 (requiring that complaint provide only short and plain statement of claim).
} 
allowing state of mind to be "averred generally." 18 The two circuits we study, the Second and the Ninth, took very different approaches to the pleading standard. Consistent with the language of Rule 9(b), before the PSLRA, the Ninth Circuit had developed a heightened pleading standard allowing plaintiffs to plead scienter generally, but demanding particularity in alleging all other elements of securities fraud. ${ }^{19}$

By contrast, the Second Circuit required plaintiffs to plead the state of mind with particularity. Prior to the PSLRA, the Second Circuit had held that plaintiffs could meet the scienter standard in one of two ways. First, plaintiffs could plead that the defendants had the motive to commit fraud and the opportunity to do so. ${ }^{20}$ Although simplistic allegations of motive that could apply generally, such as keeping one's job, ${ }^{21}$ were insufficient to meet the standard, other allegations of specific financial gain from a transaction were sufficient to state a claim. ${ }^{22}$ Second, plaintiffs could meet the standard with circumstantial evidence of either recklessness or conscious behavior. ${ }^{23}$ Generally, this standard required plaintiffs to plead contemporaneous facts, conditions, or statements to show that the defendants knew or should have known that the alleged misstatement was misleading when made. ${ }^{24}$

\footnotetext{
${ }^{18}$ Fed. R. Civ. P. 9(b).

${ }^{19}$ See In re Glenfed Sec. Litig., 42 F.3d 1541 (9 ${ }^{\text {th }}$ Cir. 1994).

20754 F.2d 1059 (2d Cir. 1985).

${ }^{21}$ See In re Crystal Brands Sec. Litig., 862 F. Supp. 745, 749 (D. Conn. 1994).

${ }^{22}$ See Goldman v. Belden, 754 F.2d 1059, 1070 (2d Cir. 1985) (holding that allegations that defendants bullish statements to market were connected to significant stock sales met motive and opportunity test).

${ }^{23}$ See San Leandro Emergency Med. Group Profit Sharing Plan v. Philip Morris Co., 75 F.3d 801 (2d Cir. 1996) (requiring plaintiffs seeking to meet recklessness standard to provide higher level of detail than that required under motive and opportunity test).

${ }^{24}$ See Shields v. Citytrust Bancorp, 25 F.3d 1124, 1129 (2d. Cir. 1994) (rejecting allegations of fraud where plaintiffs failed to contrast public disclosure with contemporaneous internal document or data).
} 
In the PSLRA, Congress resolved this split by rejecting the Ninth Circuit's approach and adopting a heightened pleading standard that drew on the Second Circuit's approach. $^{25}$ The "strong inference" provision requires that:

In any private action arising under this title in which the plaintiff may recover money damages only on proof that the defendant acted with a particular state of mind, the complaint shall, with respect to each act or omission alleged to violate this title, state with particularity facts giving rise to a strong inference that the defendant acted with the required state of mind. ${ }^{26}$

Although it is now clear that plaintiffs must plead scienter with particularity, it remains unclear how much detail is required to meet that particularity standard. The legislative history can be fairly read to require a standard equivale nt to the then-existing Second Circuit standard or, potentially, a higher standard still. ${ }^{27}$ The combination of confusing legislative history and the fact-based nature of securities fraud claims has resulted in different pleading standards across the circuits. ${ }^{28}$

Consequently, courts have struggled to apply the heightened pleading standard to various allegations of fraud. In this Article, we examine the effect of the PSLRA's heightened pleading standard as applied to decisions resolving motions to dismiss by courts within the Second and Ninth Circuits. We focus on these circuits for two reasons. First, these two circuits far outpace the others in the number of securities fraud claims litigated. $^{29}$ Second, the two circuits have interpreted the pleading standard in divergent ways, with the Ninth Circuit now recognized to have the most stringent pleading standard

\footnotetext{
${ }^{25}$ See S. Rep. No. 104-98, at 15 (1993), reprinted in 1995-96 U.S.C.C.A.N. 679, 694.

${ }^{26}$ Reform Act, Pub. L. No. 104-67, 109 Stat. 737, 746-47 (1995, codified at Exchange Act §21D(b)(2), 15 U.S.C. $\$ 78 \mathrm{u}-4(\mathrm{~b})(2))$.

${ }^{27}$ See Sale, supra note __; Grundfest \& Pritchard, supra note __.

${ }^{28}$ See Grundfest \& Pritchard, supra note _, 668-669.

${ }^{29}$ See Cornerstone Research, Securities Class Action Case Filings, 2003: A Year in Review, at 13 (reporting an average of 51 filings per year in the Ninth Circuit and 37 per year in the Second Circuit from 1996 to 2003; the next highest circuit (the $11^{\text {th }}$ ) averaged only 20 per year over the same period) (2004).
} 
in the country, and the Second Circuit believed to have the least stringent. ${ }^{30}$ These differing standards may lead to differing treatment of similar types of allegations. ${ }^{31}$

\section{B. The Safe Harbor for Forward-Looking Statements}

We also analyze the PSLRA provision creating a separate liability standard for "forward-looking statements." 32 This standard grew out of the "bespeaks caution" doctrine developed by the courts. Under this doctrine, courts would not hold defendants liable for financial projections and other forward-looking statements if those statements were accompanied by cautionary language to warn investors that the predictions might not bear out. If the warnings were sufficiently tailored, courts applying the "bespeaks caution" standard concluded that the forward-looking statements were immaterial, and thus, not actionable, even if false. ${ }^{33}$

\footnotetext{
${ }^{30}$ See Grundfest \& Pritchard, supra note __, at 671.

${ }^{31}$ A brief description of the conflicting standards may be useful to readers not familiar with this debate. The Second Circuit relied on the legislative history and held that the PSLRA codified its pre-PSLRA pleading approach. Novak v. Kasaks, 216 F.3d 300, 311 (2000). The Second Circuit has, however, refined its explication of the standard post-PSLRA. Now, rather than a two-prong test, the Second Circuit has set forth a list of the general types of allegations that will meet the heightened pleading standard for scienter. Synthesizing its own case law on the pleading standard, the Second Circuit held that plaintiffs can plead a strong inference of fraudulent intent by including sufficient allegations that the defendants: received concrete, personal benefits from the alleged fraud; participated in deliberately illegal behavior; knew or had access to facts "suggesting" that the public statements were inaccurate; or "failed to check information they had a duty to monitor." See id. at 311. This refined standard, of course, still leaves room for pleading based on motive and opportunity.

By contrast, the Ninth Circuit recognized that the PSLRA repudiated that court's old standard, which did not require that state of mind be pleaded with specificity. In interpreting the "strong inference" provision, the court also relied on the PSLRA's legislative history, but concluded that the statute raised the standard above that of the Second Circuit. See In re Silicon Graphics Inc. Sec. Litig., 183 F.3d 970, 974 (9th Cir. 1999). Under this higher pleading standard, the court rejected allegations based on motive and opportunity and on recklessness. Id. Instead, to meet its new pleading standard for scienter, plaintiffs had to plead, "at a minimum, particular facts giving rise to a strong inference of deliberate or conscious recklessness." Id.

${ }^{32}$ See Exchange Act $\$ 21 \mathrm{E}(\mathrm{c}), 15$ U.S.C. $\$ 78 \mathrm{u}-59(\mathrm{c})$.

${ }^{33}$ See, e.g., Kaufman v. Trump's Castle Funding, 7 F.3d 357, 371-372 ( $3^{\text {rd }}$ Cir. 1993) (explicating and applying "bespeaks caution" doctrine).
} 
In the PSLRA, Congress created a liability standard for forward-looking statements more restrictive than the standard for $10 \mathrm{~b}-5$ claims. Forward-looking statements are now protected by a safe harbor. To circumvent that safe harbor, the plaintiff must prove that the defendants making the statements did so with actual knowledge of their falsity. ${ }^{34}$ Although the statute does not speak directly to the pleading standard for these claims, it does state that complaints must "state with particularity facts giving rise to a strong inference that the defendant acted with the required state of mind." ${ }^{, 35}$ Further, even if the plaintiff successfully pleads actual knowledge, the statutory safe harbor bars the claim if the alleged misstatement was accompanied by meaningful cautionary language. ${ }^{36}$ As a result, courts often subject these statements to more exacting scrutiny than other general allegations of misleading statements or omissions. ${ }^{37}$

In adopting these reforms, Congress was attempting to reduce the liability exposure of issuers, accountants, and investment bankers by making securities fraud cases more difficult to litigate. Operationally, the PSLRA's principal barrier is making complaints more difficult to plead. The success of any reform to the litigation process, however, will depend both on the work of the courts in implementing those reforms and the responses of attorneys to those reforms. In the next part, we develop our hypotheses regarding the effect of the PSLRA on the litigation and resolution of securities fraud class actions.

\section{HYPOTHESES}

\footnotetext{
${ }^{34}$ Exchange Act $\$ 21 \mathrm{E}(\mathrm{c})(1)(\mathrm{B}), 15$ U.S.C. $\$ 78 \mathrm{u}-5(\mathrm{c})(1)(\mathrm{B})$.

35 Exchange Act $\$ 21 \mathrm{D}(\mathrm{b})(2), 15$ U.S.C. $\$ 78 t-5(b)(2)$.

${ }^{36} \mathrm{Id}$.

${ }^{37}$ See Hockey v. Medheker, 30 F. Supp. 2d 1209, 1221 (N.D. Cal. 1998).
} 
In this part of the article, we develop a series of hypotheses concerning the resolution of motions to dismiss in securities fraud class actions. We sort our hypotheses into three categories. The objective of our first set of hypotheses is to determine whether allegations commonly included in securities fraud complaints correlate with the outcomes of motions to dismiss those complaints, and, by inference, whether these allegations influence judges who must decide these motions. How well do plaintiffs' attorneys tailor their complaints to judges' expectations? The objective of our second set of hypotheses is to determine whether variations in the applicable legal standard lead to different outcomes. Thus, the first two sets of hypotheses attempt to capture the impact of the heightened pleading standard and the heightened liability standard for forward-looking statements on litigation. Our third set of hypotheses focuses on whether the identity of the law firm bringing the claims has an effect on the outcome.

\section{A. Type of Allegations}

As discussed above, Congress's stated purpose in enacting the PSLRA was to discourage weak or frivolous securities fraud suits. The "strong inference" pleading requirement discussed above is the key mechanism Congress deployed. Earlier work studying the effects of the PSLRA has found that plaintiffs' lawyers have attempted to satisfy this requirement by alleging that defendants have violated accounting principles. $^{38}$

A typical allegation states that the firm and its managers ignored generally accepted accounting principles (“GAAP”), provided numbers not supported by those

\footnotetext{
${ }^{38}$ PricewaterhouseCoopers, 2000 Securities Litigation Study, www.10b5.com (2000); see also Robert B. Thompson \& Hillary A. Sale, Reflections on Federalism: Securities Fraud as Corporate Governance, 54 Vand. L. Rev. 101 (2003) (analyzing key allegations in complaints filed in Second, Ninth, and Third Circuits).
} 
principles and, thereby, intentionally misled the investing public. This type of allegation provides an intuitive basis from which to infer scienter. Rules, after all, are meant to be followed; if they are not, a court could conclude that the defendants were knowingly making misleading statements about the firms' financial situation.

Allegations that the defendants inflated reported revenues may provide particularly salient evidence of scienter, implying that the defendants wanted the company's prospects to look better than they actually were. The strength of these allegations is likely to vary with the evidence that accounting principles have been violated. Restatements arguably offer particularly tangible evidence to judges of a misstatement by the company. Courts may draw stronger inferences from alleged violations of GAAP if the firm's auditors or the SEC have required it to restate its revenues. A restatement will only be required if it is concluded that prior financial statements were materially misleading, thus satisfying a central element for a $10 \mathrm{~b}-5$ claim. An allegation of an accounting violation without an accompanying restatement may provide a weaker inference. Similarly, allegations that defendants have violated accounting principles other than revenue recognition may provide a still weaker basis for inferring fraudulent intent. This analysis suggests a continuum of accounting allegations. Accordingly, we test three separate hypotheses involving accounting violations:

H1: Courts are less likely to dismiss complaints with allegations that the firm has restated revenues.

H2: Courts are less/more likely to dismiss complaints with allegations that the firm has misled investors in recognizing revenues.

H3: Courts are less/more likely to dismiss complaints with allegations of violations of GAAP other than revenue recognition. 
Post-PSLRA complaints contain other types of common allegations, though we believe the courts may perceive those allegations to be weaker than accounting allegations. For example, the increased prevalence of option-based compensation schemes in recent years has made it much easier to allege claims using insider trading as the motive from which scienter can be inferred. Moreover, the trades of officers and directors are publicly available, and therefore readily included in complaints. Such claims have in fact increased. ${ }^{39}$

The theory behind these claims is that options, and stock ownership in general, may provide an incentive for management to temporarily inflate stock prices in order to liquidate their holdings. But stock and option compensation has been so prevalent, it is also likely that there are few cases in which insider trading cannot be alleged. As a result, if plaintiffs do not exercise restraint in making such allegations, courts may discount claims relying on insider trading as an indicator of scienter - despite the intuitive plausibility of such conduct as a motive for fraud. Indeed, prior work suggests that courts are highly skeptical of such allegations ${ }^{40}$ and that the allegations are not correlated with complaints surviving a motion to dismiss. ${ }^{41}$ Accordingly, our fourth hypothesis is that:

\section{H4: Courts are more likely to dismiss complaints using insider trading to support the scienter allegations.}

\footnotetext{
${ }^{39}$ See Sale, Judging Heuristics, supra note _, 924-34 (collecting and analyzing opinions discussing insider trading allegations).

${ }^{40}$ See id, supra note __ (showing increased rejection of insider trading claims and developing heuristics court deploy in dismissal).

${ }^{41}$ Marilyn F. Johnson, Karen K. Nelson \& A.C. Pritchard, Do the Merits Matter More? Class Actions under the Private Securities Litigation Reform Act (Working paper, June 2004) (finding no association between measure of abnormal insider trading and insider trading allegations).
} 
Plaintiffs can also satisfy the scienter requirement with other allegations of motive to commit fraud. ${ }^{42}$ An offering of securities by the corporate defendant, either in the form of a public or private offering or a merger in which stock is used as the consideration, is a commonly pleaded motive for fraud. ${ }^{43}$ For example, the plaintiffs might allege that the defendants made a misstatement to keep the stock price high in order to pursue or complete a strategic combination, or that the defendants made a misstatement in order to prime the market for their offering. Our fifth and sixth hypotheses are that:

\section{H5: Courts are less likely to dismiss complaints when the issuer has offered securities during the class period.}

\section{H6: Courts are less likely to dismiss complaints when the issuer is negotiating a merger or has one pending during the class period.}

\section{B. Legal Standards}

Differences in the substantive law that judges apply to the complaints may also affect the likelihood of dismissal. Prior to the PSLRA, plaintiffs based many claims on assertions that companies had released misleading financial projections or other forwardlooking statements. ${ }^{44}$ As discussed above, the PSLRA raised the pleading requirement for all allegations, but the statutory safe harbor raises the standard of proof, and arguably the pleading standard, for claims based on forward-looking statements. ${ }^{45}$ As a

\footnotetext{
${ }^{42}$ This is true in most circuits, including the Second Circuit. See, e.g., Novak v. Kasaks, 216 F. $3 d$ d00 (2 $2^{\text {nd }}$ Cir.), cert denied, 121 S. Ct. 567 (2000). The Ninth Circuit, however, purports to reject allegations of scienter based on "motive and opportunity." See In re Silicon Graphics Securities Litig., 183 F.3d 970 (1999).

${ }^{43}$ See Sale, Judging Heuristics, supra note __, n162 (discussing use of merger and offering allegations by plaintiffs in complaints and judicial responses in motions to dismiss).

${ }_{44}$ Jennifer Francis, Donna Philbrick and Katherine Schipper, Shareholder Litigation and Corporate Disclosures, 32 Journal of Accounting Research 137 (1994).

${ }^{45}$ Securities Act $\$ 27 A, 15$ U.S.C. \$77z-2; Exchange Act §21E, 15 U.S.C. §78u-5.
} 
consequence, courts may be particularly reluctant to allow allegations based on forwardlooking statements to survive a motion to dismiss, leading to our seventh hypothesis:

\section{H7: Courts are more likely to dismiss complaints based on forward-looking statements.}

The anti-fraud provisions of the Securities Act of 1933 (which apply only to public offerings of securities) differ substantially from Section 10(b) the Exchange Act (which applies to fraud in connection with any purchase or sale of securities). In particular, Section 11 of the Securities Act provides for strict liability for corporate issuers who have made a material misstatement in a registration statement. ${ }^{46}$ Section 12(a)(2) provides a negligence claim for misstatements in a prospectus. ${ }^{47}$ Although plaintiffs must meet other hurdles to succeed with these claims, ${ }^{48}$ the PSLRA's increased pleading standard for claims based on a particular state of mind was included only in the amendments to the Exchange Act, not the Securities Act. ${ }^{49}$ Nonetheless, some courts have held that when these Securities Act claims are pleaded in the same complaint with a 10b-5 claim, the entire complaint "sounds in fraud" and is subject to the heightened pleading standard of Rule 9(b) of the Federal Rules of Civil Procedure. ${ }^{50}$ As a result, those courts have dismissed the Securities Act's strict liability and negligence claims along with the 10b-5 claim. Others have, however, refused to adopt this approach, holding that because the Securities Act claims do not require scienter, they are not subject

\footnotetext{
4615 U.S.C. $\$ 77 \mathrm{k}$.

4715 U.S.C. $\$ 77 l(\mathrm{a})(2)$.

${ }^{48}$ For a full explication of these claims and their litigation, see Hillary A. Sale, Disappearing Without a Trace: Sections 11 and 12(a)(2) of the 1933 Securities Act, 75 Washington Law Review 429 (2000).

${ }^{49}$ Compare Exchange Act Section 21D(b)(2), 15 U.S.C. $§ 78 u-4(b)(2)$ (requiring complaints to "state with particularity facts giving rise to a strong inference that the defendant acted with the required state of mind") with Securities Act Section 27, 15 U.S.C. $\$ 77 z-1$ (imposing no pleading requirements).

${ }^{50}$ See, e.g. Rombach v. Chang, 355 F.3d 364(2 ${ }^{\text {nd }}$ Cir. 2004).
} 
to a heightened pleading standard and should be allowed to proceed. Accordingly, our eighth hypothesis lacks a predicted direction:

\section{H8: Courts are less/more likely to dismiss complaints that include claims brought under the Securities Act of 1933.}

\section{Identity of Counsel}

Another factor that may influence outcomes on motions to dismiss is the identity of class counsel. During the period of our study, Milberg Weiss Bershad Hynes \& Lerach was by far the largest law firm specializing in securities fraud class actions, appearing as counsel in the majority of those suits. ${ }^{51}$ Bill Lerach, one of the firm's bestknown partners, gained notoriety during the PSLRA debates, with his boast (repeatedly cited by proponents of reform): "I have the greatest practice in the world. I have no clients." This publicity is not likely to raise one's reputation with judges. Consequently, judges familiar with the reputation of the Milberg Weiss firm may be skeptical of the claims that it brings, making complaints filed by that firm particularly susceptible to dismissal.

On the other hand, Milberg Weiss does more securities litigation than any other plaintiffs' firm. Its economies of scale may make it the firm best suited to adapt its pleadings and conform to or even anticipate shifts in the case law. ${ }^{52}$ It may also have greater resources to invest in pre-complaint investigation, which might enhance its ability to plead with particularity. Consequently, its complaints may be more likely to survive dismissal. We therefore do not have a predicted direction for our ninth hypothesis:

\footnotetext{
${ }^{51}$ The firm has subsequently split in two, with the East and West Coast offices going their separate ways. Bloomberg News, Millberg Weiss Becomes 2 Firms (May 4, 2004).

52 See Elliot J. Weiss, Pleading Securities Fraud, 64 Law \& Contemp. Prob. 5, 10-16 (2001) (analyzing the “creative drafting” of Milberg Weiss's Silicon Graphics complaint); id. at 27-44 (analyzing additional complaints by Milberg Weiss).
} 


\section{H9: Courts are more/less likely to dismiss claims brought by Milberg Weiss.}

\section{EMPIRICAL RESULTS}

We turn now to our empirical tests of the hypotheses developed in Part III. We begin by describing our sample selection. We also present descriptive statistics for the variables that that we use to capture the effect of different factors on litigation outcomes. We then discuss the results of our regression analyses.

\section{A. $\quad$ Sample selection and descriptive statistics.}

Our sample consists of decisions in the Second and Ninth Circuits ruling on motions to dismiss in securities fraud class actions. Using exhaustive searches on Lexis and Westlaw, as well as various reporters and websites, we collected every available decision (published or unpublished) by both district and appellate courts applying the PSLRA to a motion to dismiss from the beginning of 1996 through the end of 2002. Our searches yielded 213 total decisions from these circuits. We then excluded all but the last available decision in the sample for each lawsuit, leaving 155 decisions; 66 of these are from the Second Circuit and 89 are from the Ninth. Of these, the circuit court decided 9 of the cases from the Second Circuit and 11 for the Ninth Circuit; the remainder of the decisions are from the district court level.

We chose these two circuits for our study because they are the leading circuits for the filing of securities class actions. In addition, they are generally recognized as falling at two ends of the pleading spectrum on securities claims. As discussed above, the courts have adopted very different approaches to interpreting and applying the pleading provisions of the PSLRA. The Ninth Circuit has adopted the most stringent interpretation 
of that provision in its Silicon Graphics decision, requiring plaintiffs to plead that defendants were "deliberately reckless" in making the misstatements alleged to be fraudulent. ${ }^{53}$ Not surprisingly, courts adopting higher standards appear somewhat more likely to dismiss claims. ${ }^{54}$ In addition, the Ninth Circuit's percentage of all securities class action filings has declined subsequent to that decision, suggesting plaintiffs' lawyers prefer to litigate elsewhere. ${ }^{55}$ Focusing on these two circuits allows us look more carefully at how the different standards applied in the two circuits affect different kinds of allegations.

We collected the data for each of the variables from the opinions resolving the motions to dismiss or the complaints themselves. We restrict our study to these data sources because the purpose of our analysis is to study the judicial implementation of the PSLRA and the factors that influence those judicial decisions. Thus, our study focuses on the cases as presented to the judge. Our variables abstract from the picture presented to the judges, however, in that they do not capture the relative strength of the allegations as they are found in the complaints. Allegations of insider trading may vary in credibility, for example, depending on whether the insider trading alleged is unusual in amount or timing. ${ }^{56}$ This simplification is necessary to make data collection tractable, but it excludes some data that could affect our results.

It is also important to note that the revenue recognition variables are coded

\footnotetext{
${ }_{54}^{53}$ In re Silicon Graphics Securities Litig., 183 F.3d 970 ( $9^{\text {th }}$ Cir. 1999).

54 Joseph A. Grundfest \& A.C. Pritchard, Statutes with Multiple Personality Disorders: The Value of Ambiguity in Statutory Design and Interpretation, 54 Stan. L. Rev. 629, 716-736 (2002). Stock prices in the high tech sector rose after the Silicon Graphics decision, possibly indicating that investors believed that the standard would make it more difficult to sue these companies. Marilyn F. Johnson, Karen K. Nelson \& A.C. Pritchard, In re Silicon Graphics Inc.: Shareholder Wealth Effects Resulting from the Interpretation of the Private Securities Litigation Reform Act's Pleading Standard, 73 So. Cal. L. Rev. 276 (2000).

55 Michael A. Perino, Did the Private Securities Litigation Reform Act Work?, 2003 U. Ill. L. Rev. 913 , 944-947.
} 
according to the most serious allegation contained in the complaint. So a complaint that includes an allegation the firm restated its revenues will be coded as 0 for the other revenue recognition category, even if the complaint includes revenue recognition allegations other than the restatement. By contrast, if a complaint contains an allegation that a company improperly recognized revenues as well as violating other accounting principles, it is coded as a 1 for both accounting categories. With these caveats in mind, the variables are defined as follows: 
Variable

Dismissed

RestateRevRec

$\operatorname{RevRec}$

OtherGAAP

InsTrade

Offering

Merger

FwdLooking

'33 Act

Milberg

Circuit

\section{Definition}

Coded as 1 if the case is dismissed in its entirety, with or without prejudice, and 0 if any of the allegations are not dismissed.

Coded as 1 if complaint alleges that the firm restated prior revenues, 0 otherwise.

Coded as 1 if the complaint alleges that the firm deceptively recognized revenues, but without a restatement, 0 otherwise.

Coded as 1 if the complaint alleges violations of generally accepted accounting principles other than revenue recognition, 0 otherwise.

Coded as 1 if the complaint alleges insider trading, 0 otherwise.

Coded as 1 if the complaints alleges that the company offered securities (debt or equity), 0 otherwise.

Coded as 1 if the complaint alleges that the company merged or was contemplating a merger, 0 otherwise.

Coded as 1 if complaint includes an allegation of a false forward-looking statement, 0 otherwise.

Coded as 1 if complaint includes a claim for violations of Sections 11 or 12 of the Securities Act of 1933, 0 otherwise.

Coded as 1 if Milberg Weiss is class counsel, 0 otherwise.

Coded as 1 for the Ninth Circuit, 0 for Second Circuit.
Predicted

Direction 
Table 1, Panel B presents descriptive statistics for the entire sample, as well as both circuits, showing the percentage of the sample having the coded outcome or allegation.

Panel B also presents tests for differences between the two subsamples.

Table 1

Descriptive Statistics

Panel A: Decisions By Year

\begin{tabular}{|c|c|c|c|c|c|c|c|c|c|c|c|c|c|c|c|}
\hline \multirow[b]{2}{*}{ Outcome } & \multicolumn{2}{|c|}{$2^{1996} 9^{\text {th }}$} & \multicolumn{2}{|c|}{$2^{1997} 9^{\text {th }}$} & \multicolumn{2}{|c|}{$2^{1998} 9^{\text {th }}$} & \multicolumn{2}{|c|}{$2^{1999} 9^{\text {th }}$} & \multicolumn{2}{|c|}{ 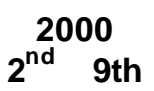 } & \multicolumn{2}{|c|}{$2^{2001} 9^{\text {th }}$} & \multicolumn{2}{|c|}{$2^{2002} 9^{\text {th }}$} & $2^{\text {Total }} 9^{\text {th }}$ \\
\hline & & & & & & & & & & & & & & & \\
\hline Dismissal & 0 & 0 & 1 & 1 & 3 & 10 & 6 & 6 & 6 & 13 & 4 & 9 & 4 & 17 & 24 \\
\hline Denial & 0 & 0 & 1 & 2 & 4 & 8 & 5 & 3 & 15 & 9 & 9 & 3 & 8 & 8 & 42 \\
\hline
\end{tabular}

Panel B: Outcomes and Allegations

\begin{tabular}{|c|c|c|c|c|}
\hline & Both $(\mathrm{N}=155)$ & 2nd Cir. $(N=66)$ & 9th Cir. $(N=89)$ & Chi Square (P-value) \\
\hline \multicolumn{5}{|l|}{ Variable } \\
\hline Dismissed & $52 \%$ & $36 \%$ & $63 \%$ & $10.703(0.001)$ \\
\hline RestateRevRec & $16 \%$ & $17 \%$ & $15 \%$ & $0.123(0.726)$ \\
\hline $\operatorname{RevRec}$ & $22 \%$ & $18 \%$ & $25 \%$ & $0.946(0.331)$ \\
\hline OtherGAAP & $32 \%$ & $35 \%$ & $30 \%$ & $0.353(0.552)$ \\
\hline InsTrade & $50 \%$ & $38 \%$ & $58 \%$ & $6.401(0.011)$ \\
\hline Offering & $28 \%$ & $42 \%$ & $18 \%$ & $11.141(0.001)$ \\
\hline Merger & $34 \%$ & $33 \%$ & $35 \%$ & $0.038(0.846)$ \\
\hline FwdLooking & $42 \%$ & $32 \%$ & $49 \%$ & $4.832(0.028)$ \\
\hline 33 Act & $17 \%$ & $27 \%$ & $10 \%$ & $7.758(0.005)$ \\
\hline Milberg & $59 \%$ & $44 \%$ & $70 \%$ & $10.344(0.001)$ \\
\hline Circuit & $57 \%$ & & & \\
\hline
\end{tabular}

Significant differences (at the $5 \%$ level) are in bold

The most striking difference in the table is the great discrepancy in percentage of motions granted. The Second Circuit courts granted $36 \%$ of motions to dismiss, and the Ninth Circuit courts granted $63 \% .^{57}$ The difference is strongly significant. This statistic provides some support for the view that the Ninth Circuit is a tougher forum in which to bring to securities fraud class actions. This raw measure does not control, however for 
the content of complaints. It is possible (although not readily explainable) that plaintiffs' lawyers bring systematically weaker claims in the Ninth Circuit. ${ }^{58}$

Consistent with the results of prior work, we find that accounting violations are common allegations in the complaints in our sample. Revenue recognition allegations appear in $38 \%$ of the complaints, and allegations of violations of other accounting principles appear in nearly a third. There is no statistically significant difference between the two circuits for any of the accounting allegation variables.

Insider trading allegations, however, are different. Allegations of insider trading are significantly more likely to appear in Ninth Circuit complaints, likely reflecting the importance of options as a form of compensation in the high tech sector.

The other allegations vary. Offering appears significantly more often in Second Circuit complaints, reflecting New York's preeminence as an investment banking center.

\footnotetext{
${ }^{57}$ The circuit court decisions are roughly consistent with these overall numbers in the Second Circuit, with the Second Circuit granting dismissal in 3 out of 9 cases. In the Ninth Circuit, however, the appellate court granted dismissal in 10 out of 11 cases.

58 Given these results and the broad venue provisions of the Securities Act and the Exchange Act, one might expect plaintiffs to file suits in the Second Circuit, rather than the Ninth. See 15 U.S.C. §77v(a), 15 U.S.C. §78aa. However, unlike general litigation, where courts give deference to the plaintiff's choice of forum, in class actions and representative litigation like the securities suits studied here, courts give considerably less weight to that choice. See, e.g., Eades v. Boston Tech., 1996 WL 668403, at * 3 (E.D. Pa. Nov. 13, 1996) (collecting and citing cases). Instead, the key factor is access to sources of proof, like documents and witnesses. See id. at $* 5$. In securities fraud class actions, it is common for defendants to seek to transfer the matter out of a district where the "only conection with the litigation [is] the residence of one or several plaintiffs, to the district containing the corporation's home office, where many of the relevant documents and witnesses are generally found in cases of this type." Bolton v. Tesoro Petroleum Corp., 549 F. Supp. 1312, 1316 (E.D. Pa. 1982); see also Kanbar v. U.S. Healthcare, 715 F. Supp. 602 (S.D.N.Y. 1999) (transferring securities fraud and other claims from New York to Pennsylvania where relevant witnesses, records, and documents were located and allegedly fraudulent conduct occurred). In addition, according to a recent study of securities fraud complaints, most suits are filed in the state where the issuer is headquartered. See Robert B. Thompson and Hillary A. Sale, Study of 1999 Securities Fraud Complaints (2004) (copy on file with authors) (of 83 complaints filed against U.S. headquartered firms in the Ninth, Second, and Third Circuits in 1999, 88\% were filed in state of issuer's headquarters). Moreover, California was the headquarters for half of the companies in the sample. Yet, California has only about $15 \%$ of the American company headquarters. Robert B. Thompson and Hillary A. Sale, Securities Fraud as Corporate Governance: Reflections Upon Federalism, 56 Vand. L. Rev. 859 n. 164 (2003). But, in securities fraud litigation, companies in the high technology industry are sued more often than others and that is consistent with California headquartered firms dominating the group in the Thompson and Sale study and here. Id. at 891.
} 
Merger appears in about a third of the complaints in each circuit. Forward-looking statements are more likely to be alleged in Ninth Circuit complaints, and the Milberg firm is more prominently represented in that circuit, appearing in more than two-thirds of the cases there. ${ }^{59}$ The Second Circuit has a significantly higher percentage of '33 Act claims, which appear in slightly less than a fifth of the cases overall.

\section{B. Regression results}

We now turn to the results of our multivariate regressions. We use logistic regression analysis with the outcome of the motion to dismiss as our dependent variable. The outcome is coded 1 if the case is dismissed in its entirety, with or without prejudice, and 0 if any of the allegations are not dismissed. Consequently, positive regression coefficients are correlated with dismissal and negative coefficients correlate with motions that are denied. The regression results are reported in Table 2.

Table 2

\section{Regression Results}

\begin{tabular}{|c|c|c|c|c|c|c|c|c|c|}
\hline \multirow[b]{2}{*}{ Variable } & \multirow[b]{2}{*}{ Prediction } & \multicolumn{2}{|c|}{ Both } & \multicolumn{2}{|c|}{ Both } & \multicolumn{2}{|c|}{ 2nd Circuit } & \multicolumn{2}{|c|}{ 9th Circuit } \\
\hline & & Coeff. & p-value & Coeff. & p-value & Coeff. & -value & Coeff. & p-value \\
\hline Intercept & $?$ & -0.330 & 0.425 & & & -0.313 & 0.597 & 0.341 & 0.547 \\
\hline RestateRevRec & - & -0.376 & 0.516 & & & -2.003 & 0.100 & 0.414 & 0.587 \\
\hline RevRec & $?$ & -0.007 & 0.988 & & & -1.455 & 0.128 & 1.002 & 0.141 \\
\hline OtherGAAP & $?$ & -0.905 & 0.024 & & & -1.531 & 0.039 & -0.860 & 0.118 \\
\hline InsTrade & + & 0.996 & 0.017 & & & 1.470 & 0.071 & 1.336 & 0.019 \\
\hline Offering & - & 0.062 & 0.890 & & & -0.216 & 0.773 & 0.185 & 0.780 \\
\hline Merger & - & 0.326 & 0.390 & & & 0.404 & 0.534 & 0.491 & 0.344 \\
\hline FwdLooking & + & -0.834 & 0.047 & & & -2.231 & 0.011 & -0.331 & 0.547 \\
\hline 33 Act & $?$ & -0.655 & 0.207 & & & 0.654 & 0.429 & -1.617 & 0.058 \\
\hline Milberg & $?$ & 0.047 & 0.904 & & & 1.385 & 0.063 & -0.615 & 0.280 \\
\hline Circuit & + & 0.982 & 0.011 & 0.654 & 0.424 & & & & \\
\hline CirRestateRevRec & & & & 2.418 & 0.093 & & & & \\
\hline
\end{tabular}

59 Although at the time this Article was written, Milberg Weiss had multiple offices, Bill Lerach headed the firm's San Diego office. 


\begin{tabular}{|c|c|c|c|c|}
\hline CirRevRec & & 2.457 & 0.036 & \\
\hline CirOtherGAAP & & 0.671 & 0.468 & \\
\hline CirInsTrade & & -0.134 & 0.893 & \\
\hline CirOffer & & 0.401 & 0.689 & \\
\hline CirMerger & & 0.087 & 0.917 & \\
\hline CirFwdLooking & & 1.900 & 0.067 & \\
\hline Cir33Act & & -2.270 & 0.056 & \\
\hline CirMilberg & & -2.000 & 0.033 & \\
\hline Pseudo $R^{2}$ & 0.123 & 0.191 & 0.189 & 0.119 \\
\hline$N$ & 155 & 155 & 66 & 89 \\
\hline
\end{tabular}

Our first regression uses the entire sample and includes Circuit as an independent variable. We find a positive coefficient on this variable, significant at the $5 \%$ level. These results are consistent with the view that courts in the Ninth Circuit are more likely to dismiss claims. This correlation between a tougher standard and an increased likelihood of dismissal suggests that the legal standard does influence outcomes.

We caution, however, against reading too much into the positive coefficient for Circuit. If the strength of the allegations in the complaints varies systematically between the two circuits, then it is possible that the Ninth Circuit is not more demanding. The significant coefficient for Circuit does imply, however, that the two circuits may differ in how they treat different types of allegations. ${ }^{60}$

Accordingly, we ran additional regressions using subsamples of the decisions from each of the circuits in order to control for the possibility that there were structural differences between the two circuits. In order to assess which variables were affected by the difference between the two circuits, we also ran an additional regression with the

\footnotetext{
${ }^{60}$ Our results may understate the magnitude of this effect because many of our district court opinions were decided before the Ninth Circuit adopted its stringent standard in Silicon Graphics in July, 1999, although the general trend was established in the district courts before that decision. Our sample is therefore potentially biased against a finding of statistical significance.
} 
entire sample adding interaction variables to capture the interaction between our independent variables and the circuit. ${ }^{61}$

1. Type of allegation

In the Second Circuit regression, the accounting variables RestRevRec and RevRec and OtherGAAP each have the predicted negative sign. The two revenue recognition variables approach statistical significance at the $10 \%$ level and these coefficients might prove to be significant with a larger sample size. OtherGAAP is statistically significant at the 5\% level. These results indicate that accounting allegations correlate with surviving a motion to dismiss in the Second Circuit.

In the Ninth Circuit, by contrast, none of accounting allegations even approach statistical significance. In our pooled regression, however, we find that the coefficients for our interaction variables are positive for all three of the accounting variables, and significant at the $10 \%$ level for the two revenue recognition variables. These results suggest that the Ninth Circuit is more skeptical of such allegations than the Second Circuit and is likely to grant a motion to dismiss even when these allegations are present.

The circuits are in accord, however, in their treatment of cases alleging trades by insiders. As predicted, we find positive and significant (at the $10 \%$ level for the Second Circuit, the 5\% level for the Ninth Circuit) coefficients for InsTrade. These coefficients support Hypothesis 4's contention that courts are skeptical of the rather noisy signal provided by such trades. Recall that these trades are pleaded in many complaints and that the presence of options as a form of pay is likely to increase trades by insiders, and, thereby, the possibility of including them in pleadings.

\footnotetext{
${ }^{61}$ The coefficients for the other independent variables are not reported here as they are identical to the coefficients for the regression using the Second Circuit subsample.
} 
Our other variables intended to capture motive to engage in fraud, Offering and Merger, are consistently insignificant. We can conclude little from this result. It is possible that motive-based allegations like offerings, mergers, and trades are not particularly persuasive to the courts (nor are they particularly unpersuasive, as insider trading appears to be) but a larger sample size might show a different result.

\section{Legal Standards}

The coefficient on the FwdLooking variable is significant in the Second Circuit and the combined sample, but with a negative coefficient, meaning that the variable relates inversely to dismissal. Thus, the sign on the coefficient is the opposite of the direction that we predicted with Hypothesis $7 .^{62}$ Rather than applying a very rigorous standard to such allegations and rejecting them, the Second Circuit appears to treat forward looking statements in a less defendant-friendly manner than we expected.

What explains this anomaly? There are at least two possibilities. The first theory is that plaintiffs' lawyers, with the stringent standard for forward-looking statements in mind, are selective in choosing forecasts and predictions upon which to base suits. When they allege such statements, they have good information to support their contentions. The second theory is that judges are skeptical of the high barrier represented by the PSLRA's safe harbor for forward-looking statements, and are therefore reluctant to vigorously enforce the safe harbor at the pleading stage. Although we cannot resolve which theory better explains this result, we consider the second less likely. After all, judges created the pre-PSLRA "bespeaks caution" doctrine without any legislative

\footnotetext{
62 The Ninth Circuit coefficient for this variable is insignificant. We note, however, that the interaction variable for this coefficient is positive and significant, suggesting the Ninth Circuit is more skeptical of such allegations.
} 
prodding. The PSLRA's safe harbor is simply an additional step in the development of that doctrine.

Our last variable relating to the effect of legal standards on outcomes is '33 Act. This coefficient is significant (at the $10 \%$ level) with the predicted negative, nondismissal, sign in the Ninth Circuit, but is insignificant in the Second Circuit (with a positive sign), despite the greater prevalence of such claims in that circuit. Thus, courts within the Ninth Circuit are ess likely to dismiss '33 Act claims than their Second Circuit counterparts. In our regressions for the combined sample, the coefficient for the interaction variable for Circuit and '33 Act is significant and negative, further supporting the proposition that the Ninth Circuit is more hospitable to such claims. We conclude that our findings support the hypothesis that Securities Act claims are more likely to be treated as non-fraud claims in the Ninth Circuit.

\section{Identity of Counsel}

Our final variable, Milberg, has a negative but insignificant coefficient in the Ninth Circuit, but a positive and statistically significant (at the $10 \%$ level) coefficient in the Second Circuit. Thus, these results indicate a correlation between dismissal and the presence of the Milberg firm in the Second Circuit. The interaction variable for Circuit and Milberg is negative and significant (at the $10 \%$ level), suggesting either that Second Circuit courts treat the firm's complaints with greater skepticism or the firm brings weaker complaints in that circuit.

\section{SUMMARY AND CONCLUSION}


The decision to file a lawsuit and the drafting of the complaint is an art, not a science. The landscape of securities fraud litigation changed dramatically in 1995 when Congress passed the PSLRA. That legislation overhauled many of the procedural and pleading aspects of securities fraud class actions, leaving the standards for making such claims highly uncertain. Notwithstanding this uncertainty, our findings suggest that social science may be able to offer insights to class action attorneys who are making filing decisions. Our study of motion to dismiss opinions since the passage of the PSLRA also suggests that the reforms have had an important impact on certain types of allegations commonly found in securities fraud complaints.

The first key reform is the heightened pleading standard. Although we do not take a position here on which circuit, the Second or the Ninth, has adopted the "correct" standard, the results of our regression analysis suggests that the standard may make a difference in outcomes. The Ninth Circuit declared its intent to adopt a standard more stringent than the Second Circuit's, and plaintiffs are now more likely to see their cases dismissed in that circuit.

But the actual knowledge standard required for forward-looking statements does not appear as formidable in the courts as it might in the statute books. Holding other allegations constant, complaints raising such claims tend to survive. We speculate that this may be due to increasingly specific pleading by the plaintiffs, but our statistical analysis does not permit us to say more. It is also possible that judges are skeptical of the fact that the actual knowledge requirement applies to pleadings as well as at trial. ${ }^{63}$

One of the most interesting aspects of our study is how the heightened pleading standard plays out with respect to specific types of allegations. The Second Circuit 
appears to find allegations of accounting violations more persuasive than does the Ninth Circuit. Of course, it is possible that complaints brought in the Second Circuit have stronger evidence of accounting wrongdoing.

The motive-based allegations find a mixed response in the courts. Trades by insiders are unpersuasive in both circuits, and the merger and offering coefficients are consistently insignificant. Finally, the Milberg Weiss firm faces more of a struggle in courts within the Second Circuit than in the Ninth. The difference in the firm's results between the two circuits may be driven by intra-firm differences as much as variations in approach by the courts.

In conclusion, our findings make clear that the law does matter. To date, the most significant obstacle to class actions is the heightened pleading standard, rather than the special forward-looking statement standard. Our results also present interesting possibilities for future study. The strongest regression results are those resulting from the application of the heightened pleading standard to allegations intended to show knowledge or motive. Plaintiffs with accounting allegations are more likely to survive a motion to dismiss in the Second Circuit; the Ninth Circuit appears more skeptical of such claims. We would hypothesize that in the wake of Enron, Worldcom, Adelphia and other accounting scandals, those allegations will continue to carry weight with the courts, and that attitudes in the Ninth Circuit courts may shift. And given the media and academic focus on the role options appeared to play in today's corporate governance scandals, it will be interesting to see whether the courts will reconsider their apparently hostile attitude toward claims alleging trades by insiders as a basis for scienter. Over time, of course, plaintiffs' lawyers may also refine their use of such allegations to mirror more

\footnotetext{
${ }^{63}$ See infra note __ and accompanying text.
} 
closely judicial doctrine. Thus, the cases decided in the next few years may reveal a shift in the courts' perspectives on what counts as fraud. 